Britain since 1960 
By the same author

GEORGE ELIOT: Godless Woman

JOSEPH CONRAD: Text and Context

HOW TO STUDY A JOSEPH CONRAD NOVEL 
Britain since Ig6o

An Introduction

\section{BRIAN SPITTLES}


All rights reserved. No reproduction, copy or transmission of this publication may be made without written permission.

No paragraph of this publication may be reproduced, copied or transmitted save with written permission or in accordance with the provisions of the Copyright, Designs and Patents Act 1988, or under the terms of any licence permitting limited copying issued by the Copyright Licensing Agency, go Tottenham Court Road, London WIP 9 HE.

Any person who does any unauthorised act in relation to this publication may be liable to criminal prosecution and civil claims for damages.

First published 1995 by

MACMILLAN PRESS LTD

Houndmills, Basingstoke, Hampshire RG2I $2 \mathrm{XS}$

and London

Companies and representatives

throughout the world

ISBN 978-o-333-6o784-8

ISBN 978-1-349-24271-9 (eBook)

DOI 10.1007/978-1-349-24271-9

A catalogue record for this book is available from the British Library

$\begin{array}{rrrrrrrrrr}\text { 10 } & 9 & 8 & 7 & 6 & 5 & 4 & 3 & 2 & \text { I } \\ \text { 04 } & 03 & \text { 02 } & \text { 01 } & \text { 00 } & 99 & 98 & 97 & 96 & 95\end{array}$


For Rod and Ann

more than relatives, good friends 


\section{Contents}

Acknowledgements $\quad$ ix

Selected Chronology $\quad$ xi

Introduction I

I Idealism and Reality: the 1918-6o Background 9

I. Britain between the World Wars 9

2. The Impact of the 1939-45 War Io

3. Conservative Power in the i95os 13

4. The New Age of the I950s I5

5. Rebellion in the I950s I5

6. Rebellion in the Streets and Cinemas 16

7. Suez and the Mass Demonstration 17

8. Immigration and Racism $\quad$ I8

9. Rebellion in the Theatre 19

2 'Money Makes the World Go Around' 22

I. I959-64: Sex, Spies and Pockets 22

2. I964-70: Labour Leads $\quad 26$

3. The 1970 Cabaret Swing $\quad 28$

4. Heath's Coal and Oil Downfall 29

5. I974: Double Cabaret Year $3^{\mathrm{I}}$

6. 'Raging inflation' 32

7. Economic Revolution 33

8. I979: 'Winter of Discontent' General Election 38

9. First Woman Premier 4I

I0. Thatcherism in Practice 43

II. 1983-7: Dogma Unleashed 47

12. I987: Fear over Hope 48

13. Thatcher's Major Defeat 50

I4. The I99os: A One-Party State? 53 
3 'Who Governs Britain?'

I. Breaking the Mould of Tyranny?

2. Rampant Regionalism: Wales and Scotland 60

3. The Irish Dimension 62

4. The Lost Legions: Trade Unions 7I

4 Battles on the Streets $\quad 82$

I. The Sixties' Time Bomb 82

2. Thatcher's Black and White Riots: 1980-I 84

3. Thatcher's Black and White Riots: $1985 \quad 87$

4. The Death of the Poll Tax 90

5 Battles for Minds 93

I. 'Genuine grievances and unreal fears' 94

2. 'Rivers of blood'? 97

3. Another 'Flood' 99

4. The Future?

5. Women's Liberation IOI

6. Liberated Women? 104

7. Dissent and Backlash $\quad$ I06

6 'b . . y furriners' 109

I. Britain Goes It Alone 1 IO

The Southern Rhodesian crisis

Britain goes it alone: the Falklands II3

'IT'S WAR!' II3

The Belgrano controversy II5

2. GB, US and UN II7

The Libyan crisis $\quad$ II9

Desert Storm 120

3. B ... y Europeans

In and out? $\quad 124$

Europe disunited $\quad{ }_{128}$

4. Britain's Other Friends $\quad$ I29

Notes

$\begin{array}{ll}\text { Index } & \mathbf{1} 37\end{array}$ 


\section{Acknowledgements}

A great many people have contributed either directly or indirectly to my understanding of the subjects in this book, and it is impossible to name them all. A few people, though, have been indispensable to me, and those I must thank. Although she may not wish to be associated with all the views expressed in it, the book would never have been written at all without the initial inspiration and encouragement of Professor Emma Harris. Her great energy and generosity of spirit provided the original impetus, and our discussions always took place in an atmosphere of good food, wine and fellowship at her table.

I would like to thank Joyce Alied for invaluable assistance. The library staff of the Bodleian have been superb, and particularly the three wonderful people running the Map Room, without whom my newspaper research would have been impossible. Val, Chris and David, at Ruskin College library, have been literally invaluable, collectively a vast source of information, ideas and good humour. Behind every academic who spends a lot of time writing there is some unsung hero who is actually doing the work back at the ranch. I wish to thank Dr Stephen Regan for taking up many of my college burdens, and remaining a good friend whilst doing so. Also I cannot register warmly enough in public my appreciation of my colleague Tom Sherry, who, woefully exploited as he has been, still shares a cup of coffee and a joke with me. Sylvie and Paul helped me with the films. Ian Seaton, Dick Alford and Nick Wadham-Smith of the British Council created the circumstances in which I was able to think about my native country with, I hope, some objectivity. I wish also to thank the many students I met through Ian and Dick for their inspirational help. As always, Margaret Wickett contributed most for least reward.

More generally I want to pay my respects to two men who have each profoundly helped to change my life. I read Richard Hoggart's first book when I was a very frustrated lathe operator, and he unwittingly put me on the educational road as an adult student. We often meet such people in the flesh with trepidation they'll have feet of clay, but subsequently meeting Richard Hoggart was no disappointment - indeed a great honour. The 
other man to change my thinking and life radically is Dr Charles Greenleaf Bell. His massive forty-two-video compilation, Symbolic History, is a great delight of learning to which I return as often as possible. It has also been my great honour to meet Charles Bell on many occasions: a man of immense genius, energy and charm without whose stimulus I would never have written anything.

The author and publisher wish to thank the following who have kindly given permission for the use of copyright material:

The Economist, for the extracts from various editions of The Economist, copyright (C) 1969, 1974, 1985, I987, 1988;

Financial Times, for the extracts from various editions of the Financial Times; Guardian News Services Ltd, for the extracts from New Society and New Statesman;

RoyJenkins, for the extracts from his 'Richard Dimbleby Lecture', BBC I (1979);

Morning Star Co-operative Society Ltd, for the extracts from issues of the Morning Star;

News Group Newspapers Ltd, for the extracts from various issues of The Sun;

Solo Syndication Ltd, for the extracts from various issues of The Daily Mail; copyright $\mathbb{C}$ Solo Syndication;

Syndication International Ltd, for the extracts from various issues of the Daily Mirror and Sunday Mirror.

Every effort has been made to trace all the copyright-holders but if any have been been inadvertently overlooked the publisher will be pleased to make the necessary arrangement at the first opportunity.

NB: By-lines are given where they are printed in newspapers and journals. If no by-line is attributed, it is because none was given in the original source. 
Selected Chronology

范宽

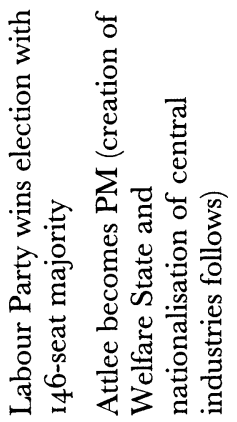

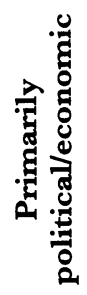

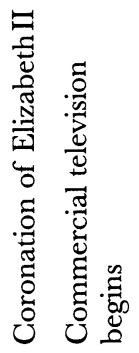

芳 芳

芑造

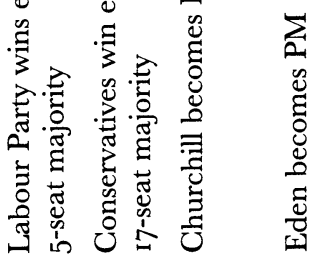

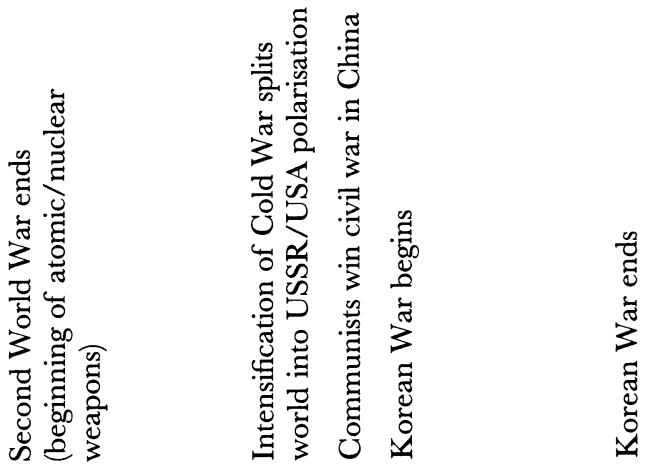

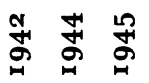

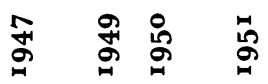

蜜㟟 


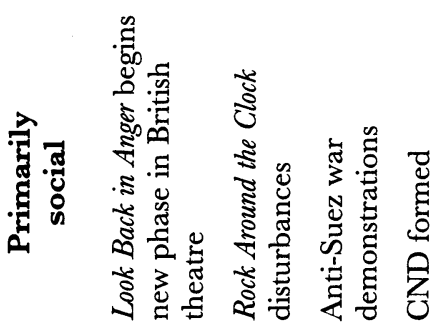

를
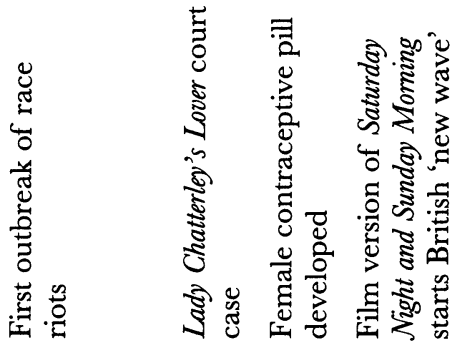

.

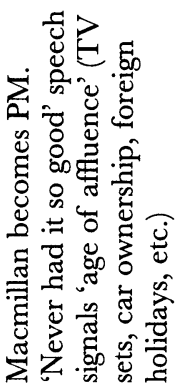

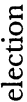

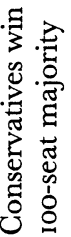
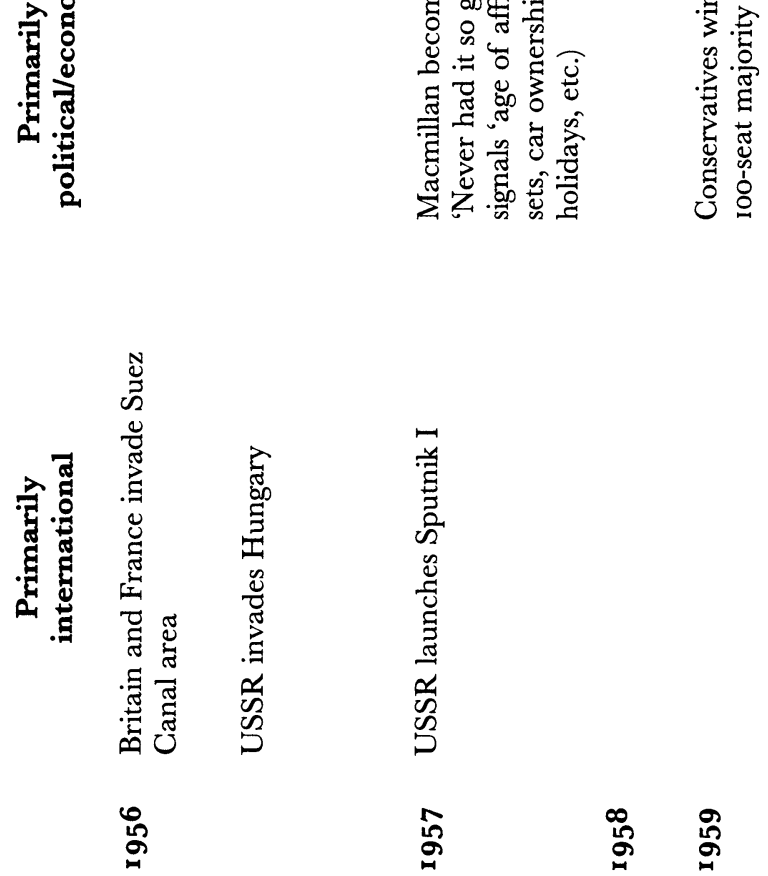

ำ

in

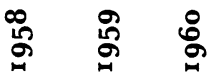



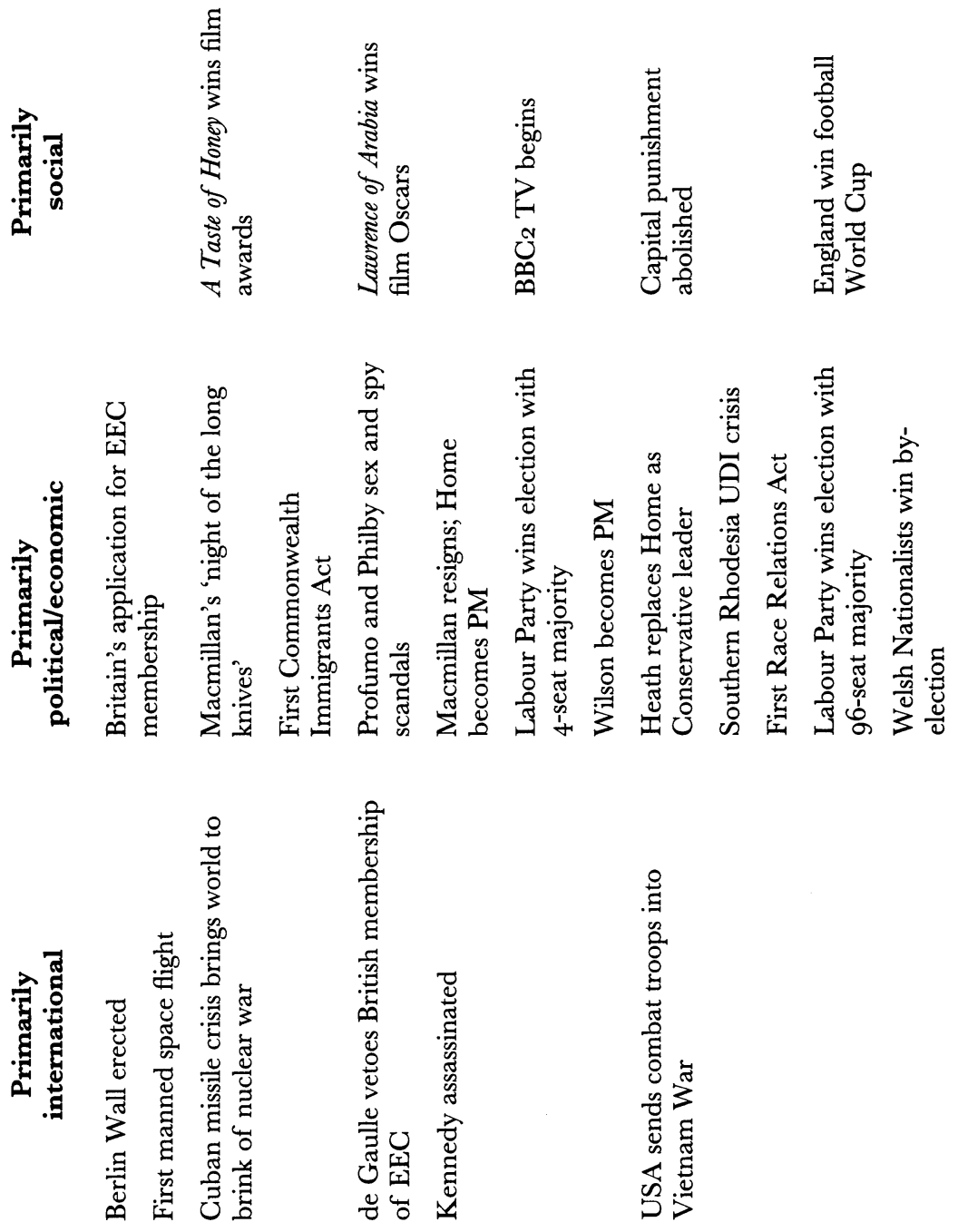

总

$\stackrel{\infty}{\circ}$

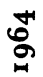

ڤ

¿ 


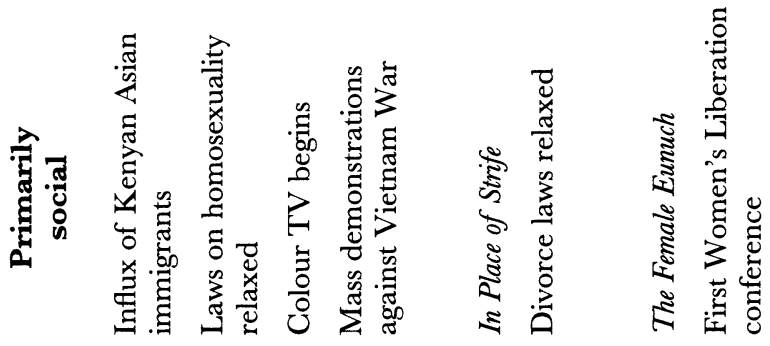
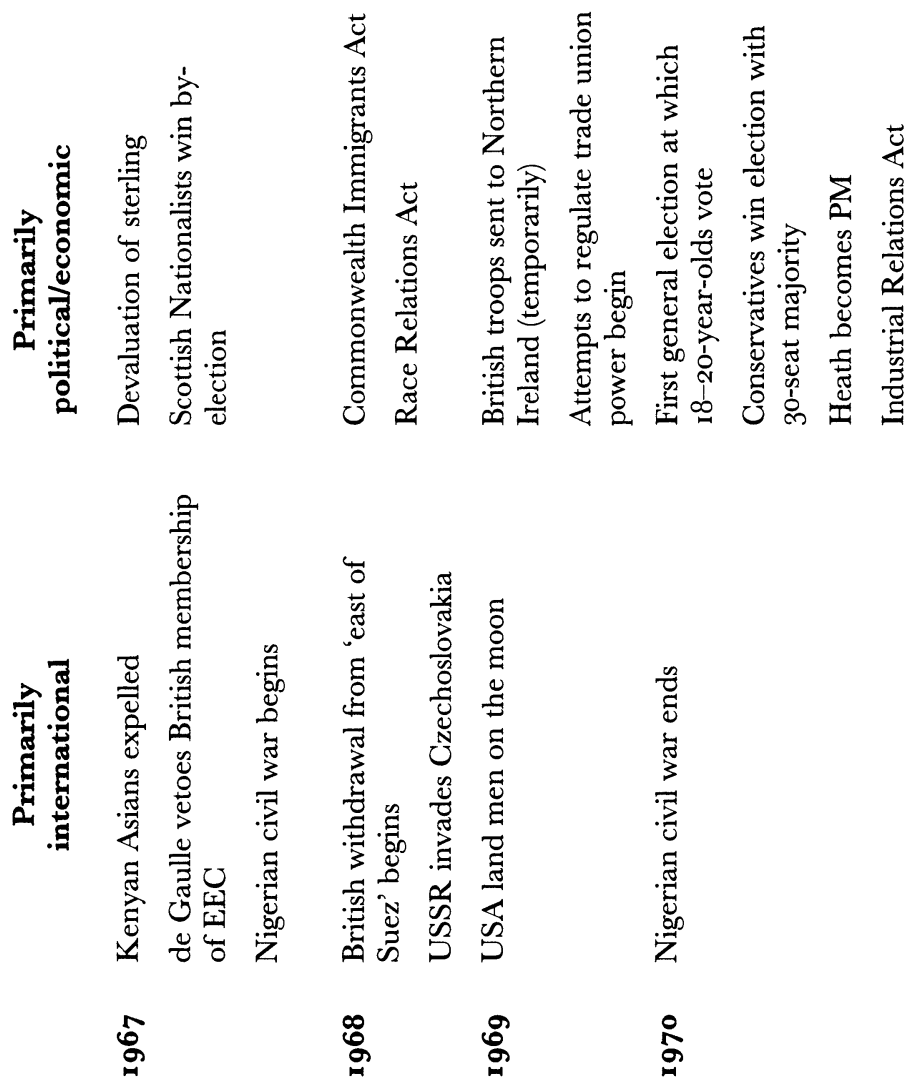

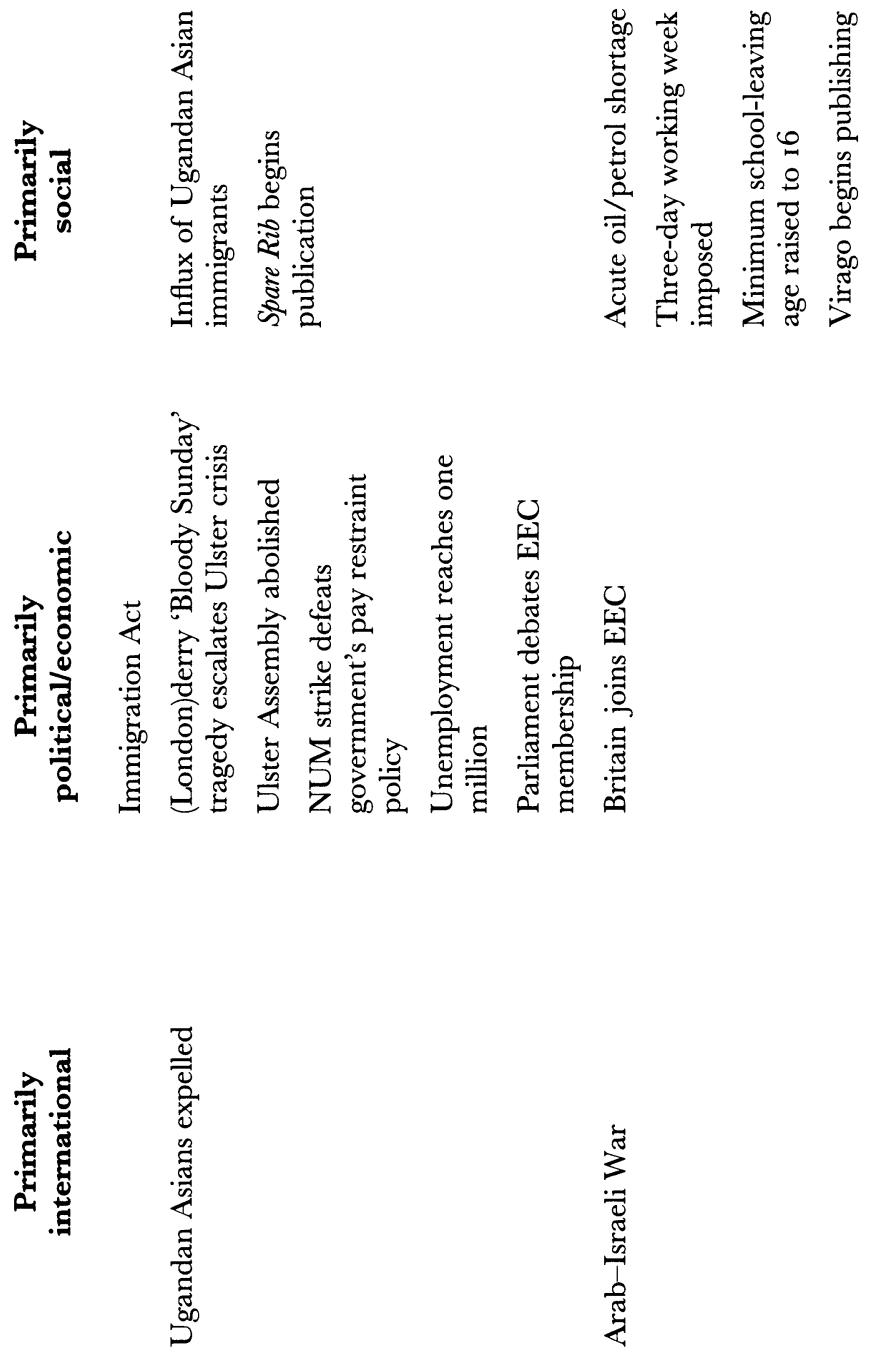

点买

$\$$ 

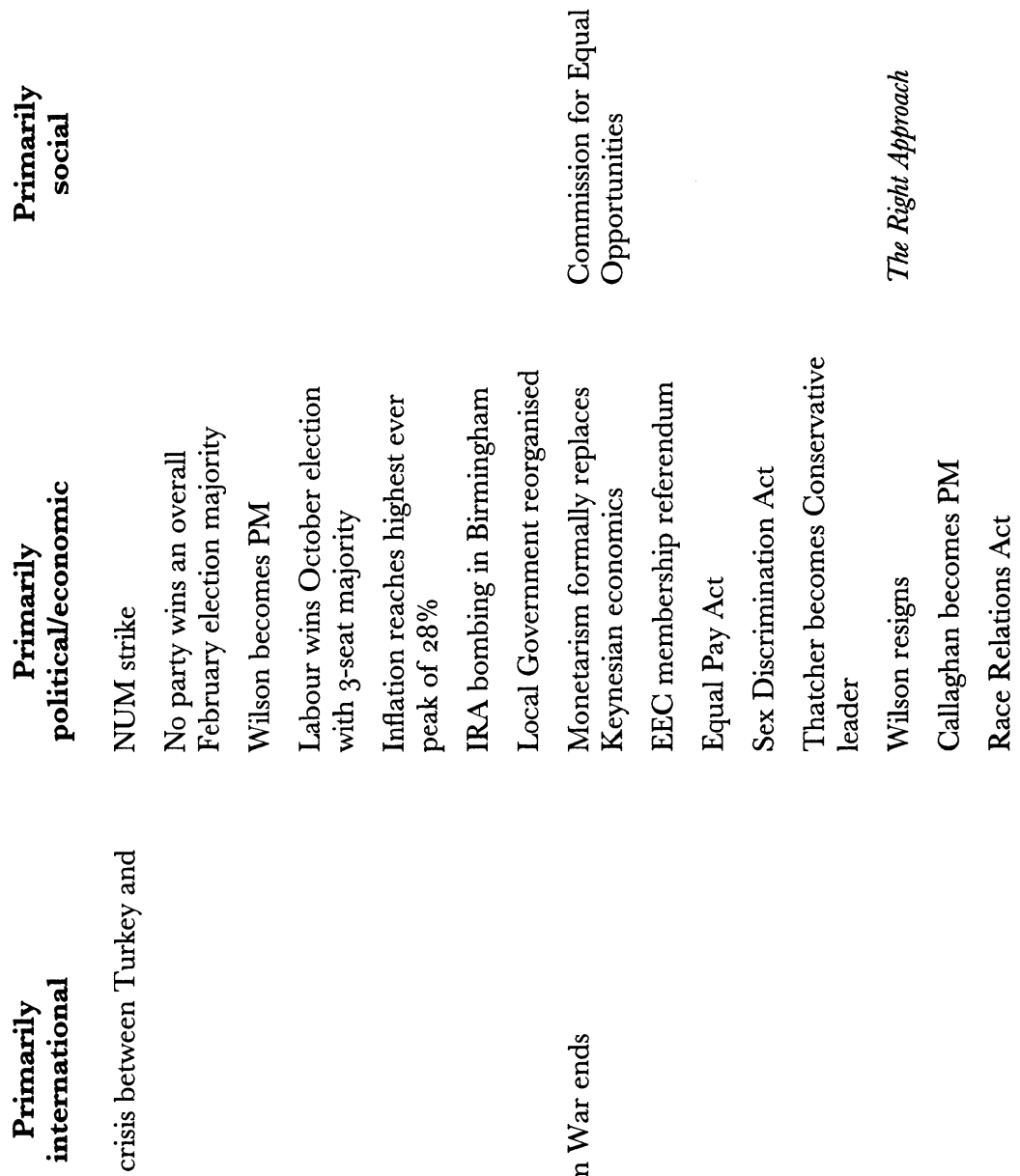

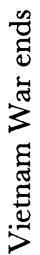

용

命 

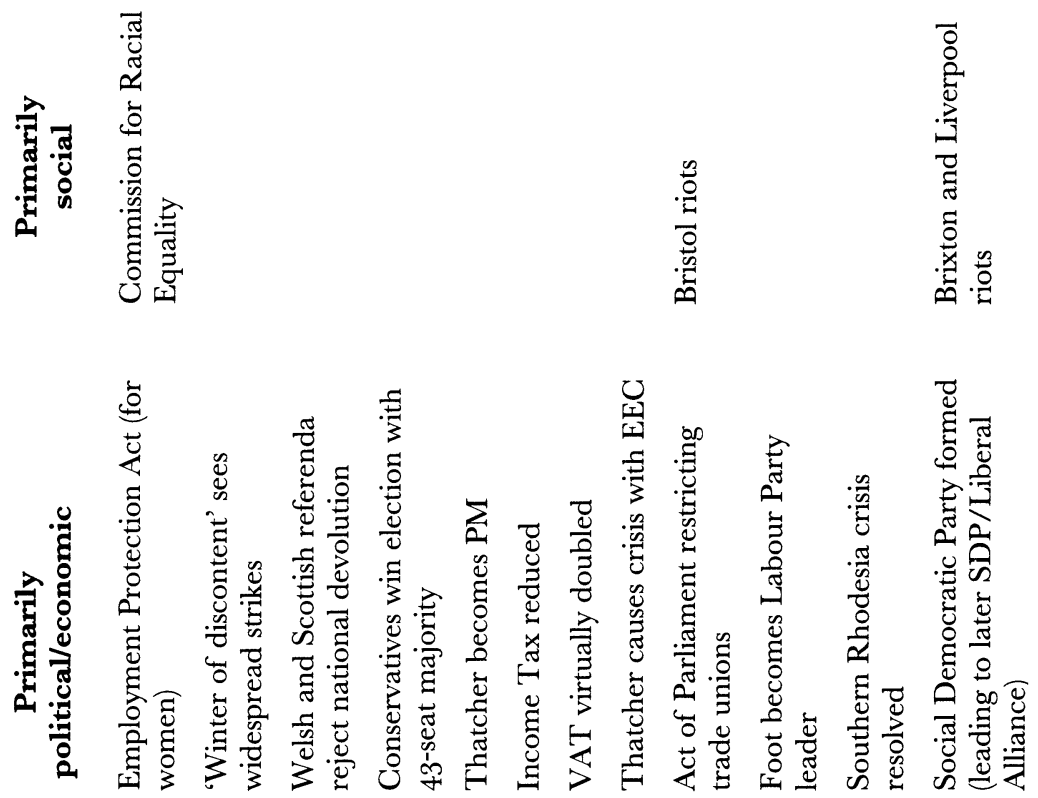

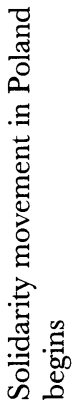

喜

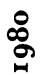

\$ 

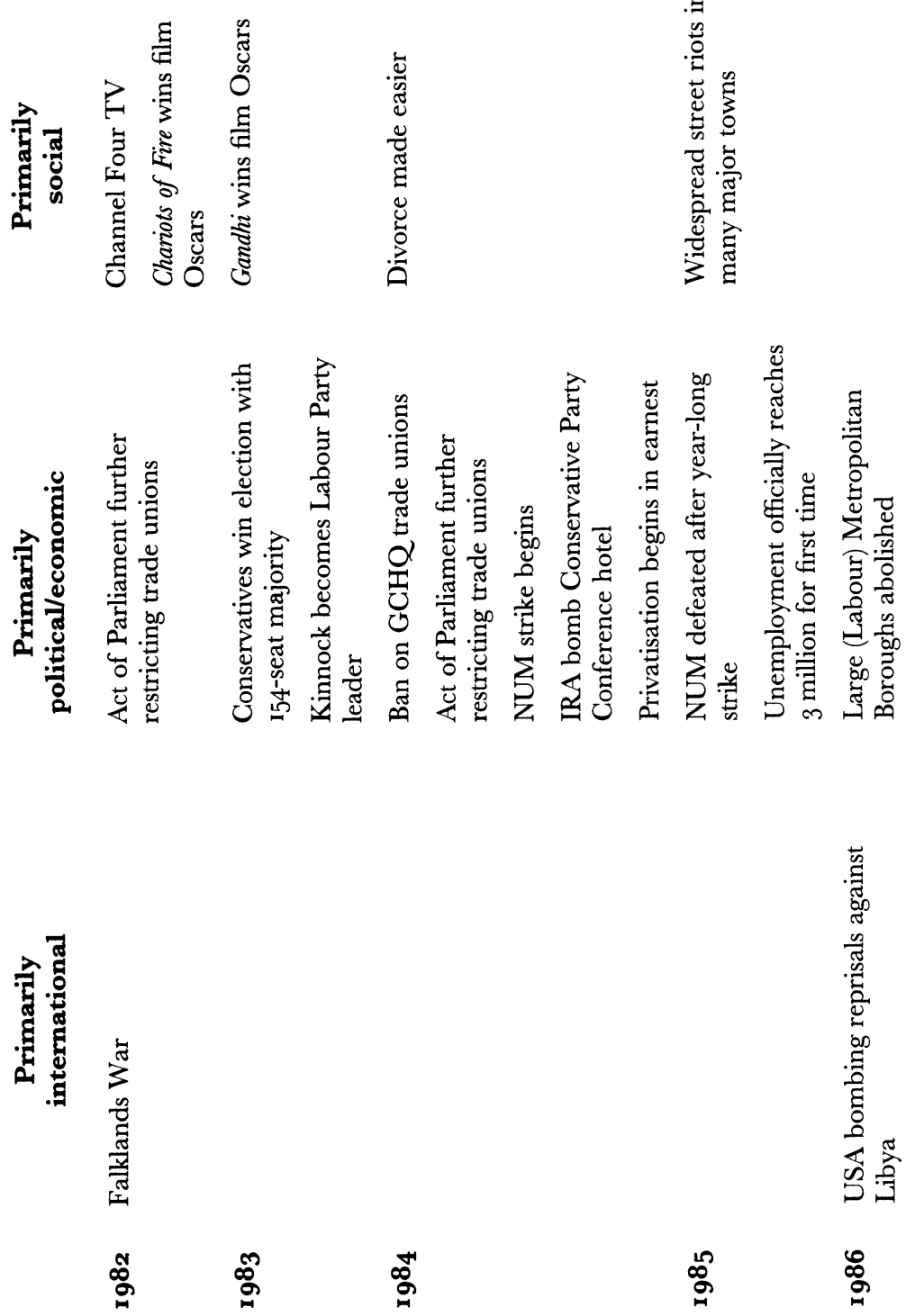

吕

ڤ్ర

$\stackrel{\infty}{\circ}$ 

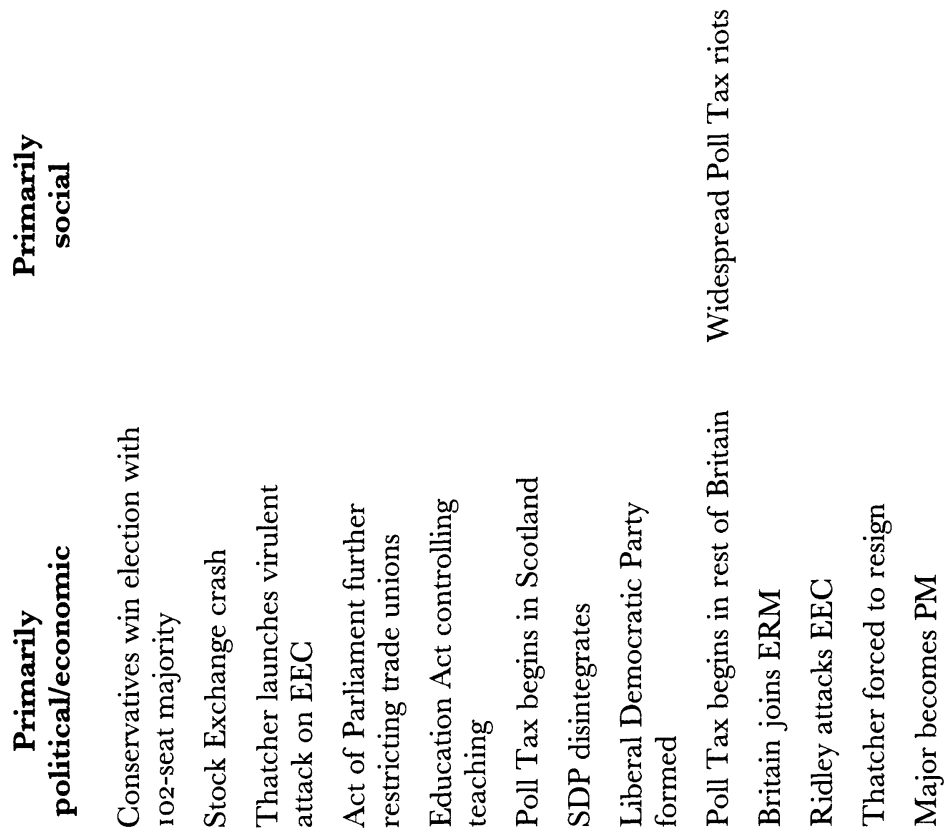

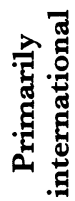

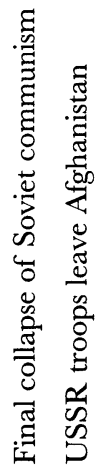

离

嵒 量 
롤

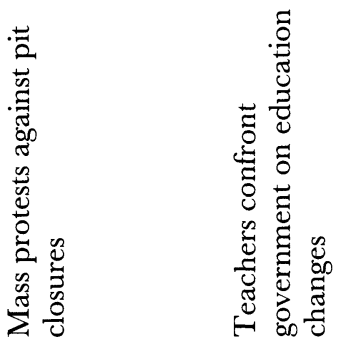

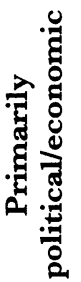
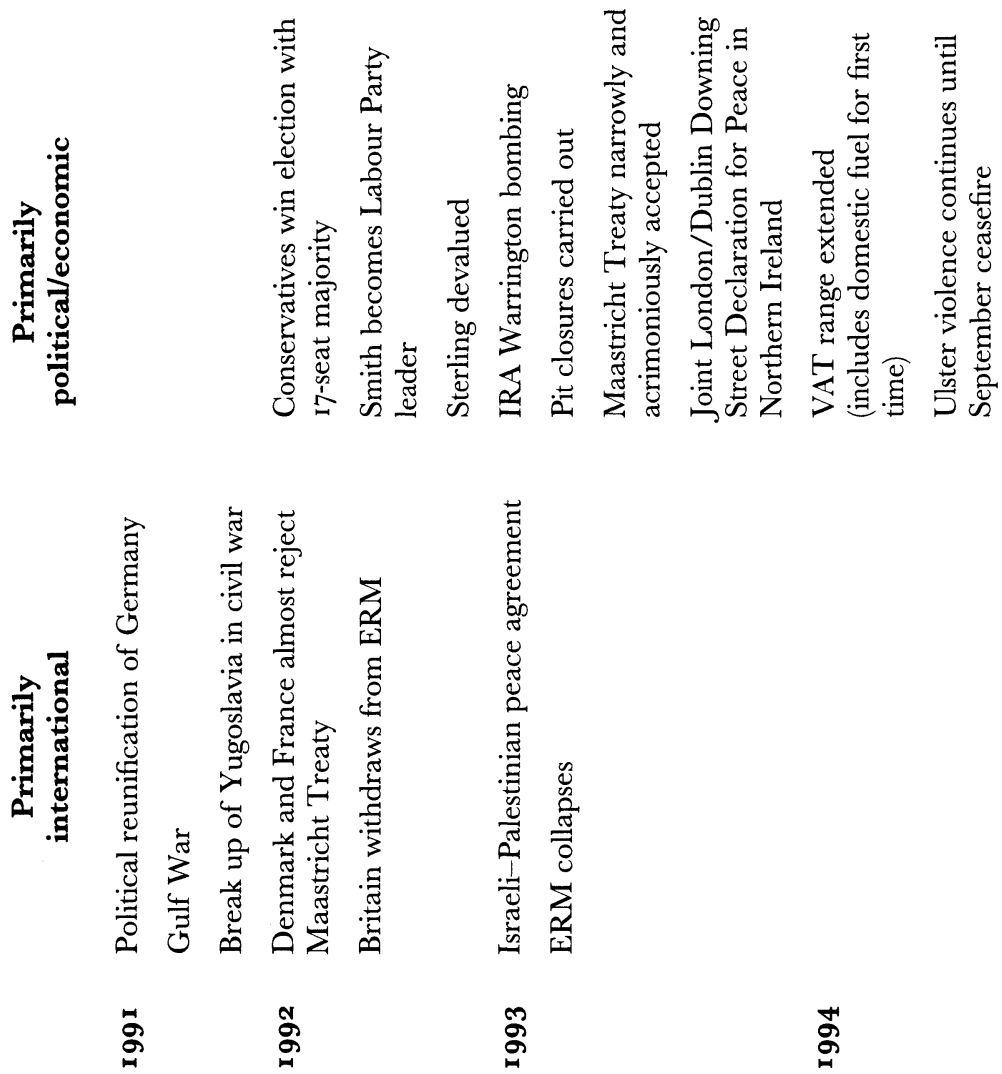

营 